RUNNING HEAD: Meta Analysis of Feedback Frequency and Appraisal Reactions

FEEDBACK FREQUENCY AND APPRAISAL REACTIONS: A META-ANALYTIC TEST OF MODERATORS

\author{
SHAUN PICHLER \\ Associate Professor of Management \\ Department of Management \\ Mihyalo College of Business \& Economics \\ California State University, Fullerton \\ GERARD BEENEN \\ Associate Professor of Management \\ Department of Management \\ Mihyalo College of Business \& Economics \\ California State University, Fullerton \\ Fullerton, CA 92831 \\ STEPHEN WOOD \\ Professor of Management \\ School of Business \\ University of Leicester
}


RUNNING HEAD: Meta Analysis of Feedback Frequency and Appraisal Reactions

\section{Feedback Frequency and Appraisal Reactions: A Meta-Analytic Test of Moderators}

\section{Abstract}

Performance appraisals provide employees with feedback that helps them improve subsequent performance, with acceptance of feedback as a key precondition to improve performance. In this study, we use the due process model of performance feedback to better understand predictors of favorable employee reactions to performance appraisal. The due process model views knowledge of performance standards and frequent feedback as aspects of adequate notice in performance appraisal, and as key predictors of favorable appraisal reactions. Empirical findings to date, however, have been inconsistent on this issue. Feedback frequency has not been consistently related to appraisal reactions in primary studies, suggesting the potential for moderator effects. We therefore meta-analyzed the relationships between knowledge of performance standards and feedback frequency with appraisal reactions through the due process lens with performance rating favorability and knowledge of performance standards as moderators. Our findings suggest prior inconsistent results could be partly explained by the moderating effects of performance rating favorability and knowledge of performance standards on the relationship between feedback frequency and appraisal reactions. We discuss the implications of our results for theory, research and practice.

Keywords

performance appraisal; due process; feedback; feedback frequency; appraisal reactions 
RUNNING HEAD: Meta Analysis of Feedback Frequency and Appraisal Reactions

Scholars and practitioners agree that managers and employees are often dissatisfied with the performance appraisal process (e.g., Taylor, Tracy, Renard et al., 1995). Managers generally do not enjoy delivering bad news, and few employees are eager to accept it (Brett \& Atwater, 2001). Nonetheless, performance appraisals should ideally provide employees with formal feedback that helps them identify performance improvement opportunities (Tziner, Murphy, \& Cleveland, 2005). How employees react to feedback during the appraisal process is linked to job attitudes (e.g., Kuvaas, 2006), as well as subsequent performance (Anseel, Van Yperen, Janssen \& Duyck., 2011; Carver \& Scheier, 1981; Jawahar, 2010; Kuvaas, 2006; Kluger \& DeNisi, 1996). Yet, performance appraisal research has not adequately addressed how to improve the performance appraisal process by understanding the mechanisms that lead to increased performance appraisal acceptance. Researchers have traditionally focused on rating formats (e.g., Latham, Fay, \& Saari, 1979) and the psychometric properties of appraisals (Balzer \& Sulsky, 1990). More recent research has focused on qualitative aspects of the appraisal process, such as relationships between employees and managers and employee reactions to performance appraisals (e.g., Cawley, Keeping \& Levy, 1998; Farndale, \& Kelluher, 2013; Levy \& Williams 2004; Pichler, 2012; Steelman, Levy \& Snell, 2004). The frequency with which employees receive feedback has been proposed as a major factor contributing to appraisal reactions and to the effectiveness of appraisals (e.g., Ilgen, Fisher, \& Taylor, 1979; Kinicki, Prussia, Wu, \& Ryan, 2001; Kuvaas, Buch, \& Dysvik, 2016; Narcisse \& Harcourt, 2008).

Yet the research on feedback frequency and appraisal reactions has produced inconsistent results (Jawahar, 2010). For example, some studies report no association between feedback frequency and appraisal reactions (e.g., Dobbins et al., 1990; Secunda, 1984, Study 1), while others report positive associations of varying strengths ranging from small (Klein \& Snell, 1994; 
RUNNING HEAD: Meta Analysis of Feedback Frequency and Appraisal Reactions

Secunda, 1984, Study 2) to large (Inderrieden et al., 2004; Shrivasatva, \& Purang, 2011A summary of variables coded and effect sizes from primary studies is included in the Appendix. The wide variation in these studies could be due to unexplored factors that moderate the relationship between feedback frequency and appraisal reactions during the performance review process (e.g., Alvero, Bucklin, \& Austin, 2001). Prior research has shown contextual factors such as supervisor-subordinate relationships and employee participation (Cawley, Keeping \& Levy, 2008; Pichler, 2012; Pichler, Varma, Michel et al., 2016), as well as employee age (Wang, Burlacu, Truxillo et al., 2015) may explain some of this variance across studies. Our goal is to explore whether the adequate notice dimension of the due process model of performance appraisal may explain variance in the relationship between feedback frequency and appraisal reactions.

Adequate notice is one of the three dimensions of due process performance appraisal, which is achieved through both frequent feedback and knowledge of performance standards (Folger, et al. 1992; Taylor et al., 1995). We suggest that the inconsistent empirical results in the literature may be due to key moderators of the relationship between feedback and employees' reactions to appraisal, namely the knowledge of performance standards and in favorability of performance ratings. Knowledge of performance standards before the review has long been identified as an important predictor of appraisal reactions (e.g., Cederblom, 1982) and a key contextual feature of effective performance management (Biron, Farndale, \& Paauwe, 2011). We propose that frequent feedback is more likely to be effective when employees are more knowledgeable of the performance standards to which they are held accountable. We also expect the favorability of the rating employees receive will moderate the relationship between feedback frequency and appraisal reactions. Although more favorable feedback is known to be positively associated with favorable appraisal reactions (Brett \& Atwater, 2001; Fedor, Eder, \& Buckley, 
RUNNING HEAD: Meta Analysis of Feedback Frequency and Appraisal Reactions

1989; Ilgen \& Hamstra, 1972), the literature has overlooked the potential interactive relationship between feedback frequency and performance rating favorability. Figure 1 displays our hypothesized model.

\section{-----Insert Figure 1 here-----}

Since appraisal reactions are critical to the overall success of a performance appraisal system (Levy \& Williams, 2004; Pichler, 2012), the purpose of this paper is to (a) enhance our understanding of the extent to which feedback frequency and knowledge of standards, are related to appraisal reactions, and to (b) identify and test moderators of the feedback-reactions relationship and thereby (c) enable us to develop a model of feedback frequency and appraisal reactions that informs future research and practice. We make recommendations regarding how organizations and human resource managers can more effectively manage performance appraisal systems to bring about more positive appraisal reactions and better subsequent performance. Our paper makes important contributions to the literatures on due process performance appraisal, performance appraisal reactions, and the broader literature on perceptions of HRM practices (Boon, Den Hartog, Boselie, \& Pauuwe, 2011).

\section{Theory and Hypotheses}

Performance management is typically characterized as a cyclical process of identifying, measuring, and developing the performance of individuals and teams (Aguinis, 2013). It begins with performance planning, where the manager ensures that the appreaisee has a clear understanding or knowledge of performance standards and expectations, and it ends with a formal performance review, often simply called the appraisal. This is a formal meeting between a manager and a subordinate employee to evaluate and discuss the extent to which performance standards and expectations were met in the prior review cycle. In between these two interactions, 
RUNNING HEAD: Meta Analysis of Feedback Frequency and Appraisal Reactions

performance planning and the appraisal, managers should provide frequent feedback, which may be informal or built into the appraisal process, such as periodic reviews. This is an ideal model, which organizations may or may not follow. In the opposite case the process is truncated into a formal infrequent periodic appraisal (typically once a year) in which the planning is conducted and no feedback is provided between these infrequent periodic appraisals (Steelman, Levy \& Snell, 2004).

Frequent feedback and knowledge of performance standards are crucial for applying the legal theory of due process to performance appraisal (Folger et al., 1992). The principles of the due process of law, which are prescribed by the Fifth and Fourteenth amendments to the U.S. Constitution, include adequate notice (notification of charges and proceedings), a fair hearing (one can present evidence on one's behalf and prepare a legal defense) and judgment based on evidence (judgments that are impartial, free from bias). In the context of performance appraisal, setting standards or expectations in the planning stage and giving feedback between this stage and the formal appraisal provide the adequate notice dimension of due process (Folger, et al, 1992: 143; Taylor et al, 1995: 496). The remaining due process criteria-fair hearing and judgment on evidence - are fulfilled through the appraisal itself, appeals procedures, and ensuring judgments at all stages are based on relevant evidence. We chose to focus on feedback frequency and knowledge of performance standards as predictors of performance appraisal reactions because they are both key aspects of adequate notice in due process, and because knowledge of standards may impact upon how feedback frequency is related to appraisal reactions (Folger et al., 1992). The fair hearing dimension has been meta-analyzed previously (Cawley et al., 1998) and is therefore outside the scope of this study. The judgment based on evidence dimension has only been 
RUNNING HEAD: Meta Analysis of Feedback Frequency and Appraisal Reactions

investigated infrequently and consequently there are insufficient primary studies to conduct a meta-analysis.

Due process theory was developed in response to the "test metaphor" of performance appraisal, which focuses on the psychometric properties of performance ratings (Folger et al., 1992). The test metaphor of performance appraisal relies on three assumptions: that work performance can be measured validly and reliably, that raters can evaluate performance accurately,; and that an ultimate performance criterion exists. Folger et al. (1992) questioned these assumptions as raters are susceptible to systematic errors and are biased by political and motivational factors. Multiple goals and mixed motives may further confound the integrity of the appraisal process. In contrast, the starting point of due process theory is that achieving fairness should be a key goal of performance appraisal (Folger et al., 1992). In that connection, a general proposition of this theory is that when employees perceive the appraisal process as fair, they will react more favorably to that process. Relatedly, Folger and colleagues (1992) argued that due process can enhance both procedural justice (i.e., making performance appraisal systems procedurally fair), and interactional justice (i.e., providing employees with more complete information).

An implication of due process theory for both research and practice is that employee reactions, such as perceptions of fairness, should be a defining criterion for gauging efficacy of the performance appraisal process (Pichler, 2012). Employee reactions to performance appraisal are measured by perceptions of accuracy, performance appraisal fairness and utility, satisfaction with the appraisal, motivation to improve performance, and perceptions of organizational justice (e.g., Keeping \& Levy, 2000). Previous meta-analyses have treated performance appraisal reactions as a composite variable first, given that they all represent appraisal reactions and second, because 
RUNNING HEAD: Meta Analysis of Feedback Frequency and Appraisal Reactions

there are too few primary studies in the empirical literature to look at meta-analytic correlations with individual reaction criteria (Cawley et al., 1998; Pichler, 2012).

Feedback frequency. Frequent feedback is central to the due process model yet it also is neglected in most organizations that tend to focus on the formal periodic (annual or bi-annual) appraisal. We define feedback as information that allows individuals to determine how well or poorly a job has been done (Greller, 1975). Frequency is a key factor in models that explain reactions to performance feedback (e.g., Dobbins et al., 1990; Ilgen et al., 1979; Lam et al., 2011; Landy, Barnes, \& Murphy, 1978; Kinicki, Prussia, Wu \& McKee-Ryan, 2001). Frequent feedback is typically assumed to be informal, though it can also occur in more formal periodic performance evaluations or discussions (London \& Smither, 2002). Due-process theory posits frequent feedback during the appraisal process facilitates a discussion between a manager and the ratee in order to enable behavioral change between the planning stage and the formal performance appraisal review (Agunis, 2013). It is typically expected that feedback frequency to be positively related to favorable reactions (e.g., Kinicki et al., 2004; Zander \& Gyr, 1955) based on three primary rationales.

First, given that feedback is a necessary condition for learning, feedback frequency should yield more favorable reactions as employees turn attention and effort towards their own learning and performance improvement. Feedback will provide valuable information that will enable employees to correct errors (Lurie \& Swaminathan, 2009). Feedback provides cues that enable employees to assess their progress towards established goals, which can positively affect their well-being (Greller \& Parsons, 1992; Holahan \& Gottlieb 2001) and result in more favorable performance appraisal reactions. 
RUNNING HEAD: Meta Analysis of Feedback Frequency and Appraisal Reactions

Second, more frequent feedback should provide employees with information that is timely and relevant for their current work assignments. Consequently, employees will be less likely to be surprised by the appraisal results and their appraisal reactions should be more favorable. Effective appraisals give employees a sense of control over the appraisal process and reduce unwelcomed appraisal surprises by aligning expectations with experience (Evans \& McShane, 1988; Lind \& Tyler, 1988). This is consistent with due process that emphasizes how adequate notice through frequent feedback gives employees voice in the process.

Third, organizational justice theory, which Folger et al. (1992) use in their development of due process theory, also helps explain why feedback frequency enhances appraisal reactions. Frequent feedback should increase the extent to which the appraisal is based on valid and accurate information (Folger et al., 1992, Leventhal, 1980), which will positively influence perceptions of the appraisal's procedural and substantive justice (Landy, Barnes \& Murphy, 1978; Lind \& Tyler, 1988). Feedback interactions provide an opportunity for employees to present their case, which constrains the power of managers to distort appraisal results (Taylor, et al, 1995: 503). Moreover, as feedback interactions increase or become institutionalized, employees may be more motivated to seek feedback themselves (Beenen, Pichler \& Levy, 2017; Steelmen, et al, 2004:169). Frequent feedback may also enhance perceptions of interactional justice as employees receive more adequate and complete explanations about their performance (Bies \& Moag, 1986; Cleveland \& Murphy, 1992). Consequently, since justice perceptions are positively associated with well-being (Wood, et al. 2016), we expect the increased sense of justice that feedback provides will yield favorable appraisal reactions (Ashford \& Cummings, 1983).

We therefore predict:

Hypothesis 1: Feedback frequency will be positively related to appraisal reactions. 
RUNNING HEAD: Meta Analysis of Feedback Frequency and Appraisal Reactions

Knowledge of performance standards. The purpose of performance planning is to ensure that employees understand their performance standards or expectations (Aguinis, 2013). In this connection, Folger et al. (1992) explain that “... due notice given via the publication, distribution and explanation of standards for performance" (pg. 143) is essential to appraisal effectiveness and favorable performance appraisal reactions. Knowledge of performance standards before the appraisal review, which includes knowledge of goal setting processes (Jawahar, 2010) and of the performance appraisal system (Levy \& Williams, 1998), has long been identified as a key predictor of performance appraisal reactions (e.g., Cederblom, 1982). Knowledge of performance standards ensures that employees know how to effectively prioritize and accomplish their work. This is especially important when employees have multiple tasks and goals. In the appraisal process, managers should formally meet with employees at the start of a performance management cycle, although this is often incorporated into the formal appraisal as goals are determined during the review of past work.

Due process theory suggests adequate notice as expressed through knowledge of performance standards should be positively associated with perceptions of performance appraisal fairness, and consequently, favorable appraisal reactions. A key reason why knowledge of standards is important is that employees should not be held accountable to performance standards "unless sufficient efforts have been directed to making these standards known and understood" (Folger et al.: 143). Increased knowledge about the appraisal process creates shared understanding between the parties and improves employees' justice perceptions (Folger et al., 1992). Goal achievement and progress towards goals, not goal setting itself, positively affects well-being (Carver \& Scheier, 1990). Knowledge of performance standards enables employees to match their work performance to a level required for optimal rewards (Lind \& Tyler, 1988). The procedural 
RUNNING HEAD: Meta Analysis of Feedback Frequency and Appraisal Reactions

justice criterion that processes are based on prevailing moral and ethical standards (Leventhal, 1980) is fulfilled to the extent that it is unethical for employees to be kept in the dark regarding their employer's performance standards. This adds to their perceptions of procedural fairness of the appraisal process and perhaps more generally of the organization. In so far as adequate knowledge of performance standards increases the employee's expectancy that they can achieve required standards, it may also increase their perceptions of distributive justice.

Research has linked employee knowledge of performance standards to more favorable reactions to performance appraisals (e.g., Levy \& Williams, 1998; Williams \& Levy, 2000). Knowledge of performance standards is related to higher levels of consistency between self- and supervisor-ratings of performance (Williams \& Levy, 1992). Employees often react negatively to discrepancies with their manager in terms of performance ratings (Levy, Cawley, \& Foti, 1998), so if knowledge of performance standards can increase consistency of self- and supervisor-rated performance, more this could result in more favorable appraisal reactions. Controlling for performance rating favorability, knowledge of performance standards is also related to more positive job attitudes (Levy \& Williams, 1998). When employees are more satisfied with their work and feel more committed to their organization, they are more likely to react favorably to performance appraisals (Kuvaas, 2006).

Hypothesis 2: Knowledge of performance standards will be positively related to appraisal reactions.

\section{Moderators of the Relationship Between Feedback Frequency and Appraisal Reactions}

Although theory predicts a positive relationship between feedback frequency and appraisal reactions, findings to date have been inconsistent. As noted earlier, some studies report no association between feedback frequency and appraisal reactions (e.g., Dobbins et al., 1990; 
RUNNING HEAD: Meta Analysis of Feedback Frequency and Appraisal Reactions

Secunda, 1984, Study 1), while others report positive associations of varying strengths from small (Klein \& Snell, 1994; Secunda, 1984, Study 2) to large (Inderrieden et al., 2004; Shrivasatva, \& Purang, 2011). No published research to our knowledge has attempted to examine these inconsistent findings. Variance in findings across studies suggests the relationship between feedback frequency and appraisal reactions may be contingent on other key elements of the appraisal process.

We propose that knowledge of performance standards and performance rating favorability both have moderating effects on the relationship between feedback frequency and appraisal reactions. We chose these variables as potential moderators based on due process theory (Folger et al., 1992). We also leveraged key theoretical models of the performance appraisal process, which suggest that knowledge of performance standards (Folger et al., 1992; Inderrieden et al., 2004; Shrivasatva, \& Purang, 2011; Steensma \& Otto, 2002) and performance rating variability (Kinicki et al., 2004; Klein \& Snell, 1994; Pichler et al., 2016) are closely tied to frequent feedback and performance appraisal reactions. When it comes to moderators in meta-analysis, "correlations between moderator variables and effect sizes sometimes point to associations that are very helpful to understand" (Rosenthal \& Dimeatteo, 2001: 66). Our general proposition here is that if knowledge of performance standards and performance rating favorability are conceptually related to and correlated with feedback frequency and to appraisal reactions, they may moderate the relationship between feedback frequency and appraisal reactions. Although these relationships may be important, they have not been tested to our knowledge in any primary or meta-analytic study.

Knowledge of performance standards. While frequent feedback and knowledge of performance standards fulfils the adequate notice principle of due process, feedback is unlikely to 
RUNNING HEAD: Meta Analysis of Feedback Frequency and Appraisal Reactions

be effective without benchmarks against which to gauge performance. Consequently, we expect knowledge of performance standards will have a synergistic effect with feedback frequency on appraisal reactions. In a review of research on feedback in organizations, feedback combined with an array of supporting activities (i.e., staff training, task analyses and information, supervisor prompts, etc.) was more effective in improving job performance than feedback alone (Alvero et al., 2001). Indeed, frequent feedback in and of itself may not always improve performance particularly if the feedback lacks clear contextual information about performance standards and prescriptive recommendations for improving performance (e.g., Chhokar \& Wallin, 1984). We posit this synergy between frequent feedback and knowledge of performance standards should occur for three reasons.

First, while frequent feedback should enhance the development of shared understandings of performance standards enabling the appraisal to become a learning process, adequate planning should accentuate this process. Performance planning and goal-setting, which generate knowledge of performance standards, will provide context to this learning so that understandings are more realistic and based on "adequate explanation", which entails comprehending how and why goals should be achieved (Folger et al., 1992: 143). On the other hand, if frequent feedback is given in the context of poor planning and inadequate explanation, learning opportunities will be limited and employees will feel powerless to improve their performance.

Second, planning enables the feedback to be grounded in shared expectations as employees have a chance to discuss or review their goals with supervisors. As more feedback is offered with greater clarity around performance expectations, a shared mental model of the appraisal process should help employees feel a greater sense of control over their performance, and enhance their perception that the process is just. This could increase employees' sense of procedural and 
RUNNING HEAD: Meta Analysis of Feedback Frequency and Appraisal Reactions

interpersonal fairness, thereby amplifying the compound effect of appraisal frequency and knowledge on employees' reactions to feedback.

Finally, as a more complete picture of the appraisal process emerges through frequent feedback exchanges, employees should experience a greater sense of coherence and orderliness in their work lives as the formal appraisal approaches. Conversely if the planning is insufficient, the lack of coherence and orderliness will impair the effect of frequent feedback on appraisal reactions. Research indirectly supports this as appraisal reactions are more favorable when managers have been trained in both goal setting and providing frequent feedback, compared to providing frequent feedback alone (Ivancevich, 1982).

Hypothesis 3: Knowledge of performance standards will moderate the relationship between feedback frequency and appraisal reactions such that the relationship between feedback frequency and appraisal reactions will be stronger (weaker) as knowledge of performance standards increases (decreases).

Performance rating favorability. In addition to feedback frequency, performance feedback favorability - otherwise known as feedback sign or performance rating favorability - has long been viewed as a key aspect of the feedback environment (see Ilgen et al., 1979; Kinicki et al., 2004). Performance rating favorability is the degree to which the subordinate being evaluated in the performance appraisal receives favorable performance feedback (Pichler, 2012). Kinicki et al., 2004; Podsakoff \& Farh, 1989). Positive performance ratings are associated with favorable appraisal reactions (Dipboye \& DePontbriand, 1981; Mesch, Farh, \& Podsakoff, 1994; Pichler, 2012). Conversely, performance appraisal research consistently has shown that low appraisal favorability is commonly perceived as inaccurate, unlikely to be accepted by the ratee, and related to negative reactions (e.g., Ilgen et al., 1979). In fact, performance rating favorability traditionally 
RUNNING HEAD: Meta Analysis of Feedback Frequency and Appraisal Reactions

has been thought to be one of the most important predictors of employee reactions to performance appraisals. Notwithstanding, performance rating favorability and feedback frequency also are intertwined, such that more frequent feedback is positively related to more favorable ratings (Ilgen et al., 1979).

This being the case, the effects of feedback frequency on appraisal reactions may be amplified by rating favorability. Employees' sense of justice generated by frequent feedback may be reinforced when feedback is positive as it adds credibility to both the shared understandings that emerge in the feedback interactions, and to the positive formal feedback received at the end of the review cycle. Employees tend to self-inflate assessments of their own performance (Holzback, 1978; Conway \& Huffcut, 1997), and frequent feedback can reduce the potential for self-inflation and lead to a greater agreement with their appraiser's performance ratings and higher levels of feedback acceptance and satisfaction (Blakely, 1993). Since employees react more positively to favorable performance ratings (Dipboye \& DePontbriand, 1981; Pichler, 2012), the relationship between frequent feedback and appraisal reactions should be stronger when performance ratings are more favorable because employees are going to feel that attending to this feedback was rewarded. Furthermore, perceived injustice of the appraisal process is likely to be reinforced when employees receive both little or no feedback, and a low rating, violating due process. We therefore hypothesize:

Hypothesis 4: Rating favorability will moderate the relationship between feedback frequency and appraisal reactions such that the relationship between feedback frequency and appraisal reactions will be stronger (weaker) as appraisal favorability increases (decreases).

\section{Methods}

\section{Literature Search and Inclusion Criteria}


RUNNING HEAD: Meta Analysis of Feedback Frequency and Appraisal Reactions

Literature review. To identify studies, we searched relevant databases, (i.e. PsycInfo, Business Source Elite, Jstor, Proquest, Sage Journals Online, and Social Science Abstracts) using keywords such as "employee reactions and performance appraisal" and "organizational justice and performance appraisal". We also used reference lists of major reviews related to contextual or qualitative aspects of performance appraisal (i.e. Cawley, Keeping \& Levy, 1998; Erdogan, 2002; Levy \& Williams, 2004; Levy et al., 2015) for unidentified articles. To minimize any publication bias or file drawer effect, we searched for relevant unpublished theses and papers, conference papers from SIOP and Academy of Management. Finally, we sent emails to the human resources and organizational behavior listservs of the Academy of Management requesting published or unpublished studies of employee reactions to performance appraisals.

Inclusion criteria. We used three criteria to evaluate studies for inclusion in our metaanalysis. First, given our central interest in employee reactions, we included only studies that measured a relationship between one or more employee reaction criteria and one or more measures of adequate notice (i.e., knowledge of performance standards or frequent feedback). Second, each study had to include actual performance review sessions. Both laboratory and field studies were included in the database since there is no a priori rationale for differences across study type in substantive relationships between appraisal processes and reactions (Levy, Cawley, \& Foti, 1998). Although there are fewer lab than field studies, researchers have found convergent results when testing the same relationships between appraisal processes and subsequent reactions in both settings (cf. Levy, Cawley, \& Foti, 1998). Finally, the study must have reported an effect size (i.e., $r$ or d), or sufficient information to calculate an effect size. Any time an effect size was not reported in a manuscript, we contacted authors to obtain the relevant data and in most cases we received responses from authors with effect size data. Whenever a 
RUNNING HEAD: Meta Analysis of Feedback Frequency and Appraisal Reactions

study reported multiple correlations between a contextual antecedent(s) and an employee reaction(s), non-independent effect sizes were transformed into a correlation of composite variables (see Lipsey \& Wilson, 2001), using Nunnally \& Bernstein (1994) formula. All of these procedures are consistent with meta-analyses published in the human resource management literature (e.g., Pichler, 2012; Schneid, Isidor, Li, \& Kabst, 2015).

The studies included in our analysis are marked with an asterisk in the References.

Effect sizes were analyzed from 5,227 respondents across 18 unique samples from 16 studies for feedback frequency; effect sizes were analyzed from 5,317 responses across 19 unique samples from 17 studies for knowledge of performance standards.

\section{Study Coding}

Primary studies were coded for measures of feedback frequency and knowledge of performance standards (see Appendix for details). An example of feedback frequency is providing feedback, i.e, “... the raters' ability to provide clear, timely, frequent, and constructive feedback to their subordinates" (Shrivastava \& Purang, 2011; see also Thurston, 2001). Another example would be perceived regular feedback, i.e., "day-to-day feedback outside of formal feedback systems such as PA" (Kuvaas, 2011,pg. 127), and feedback frequency or "How often does your supervisor tell you [if] you are doing well overall” (Kinicki et al., pg. 1061).

An example of knowledge of performance standards is the "perceived system knowledge" scale developed by Williams and Levy (1992), which measures "the level of knowledge and understanding an employee reports having about the standards, criteria, and objectives of his/her performance appraisal system" (Williams \& Levy, 2000, pg. 505) and is used in several studies (e.g., Feys et al., 2008; Levy \& Williams, 1998;),. This scale is similar to the knowledge of appraisal criteria item used by Erdogan (2001), which asked "Before the 
RUNNING HEAD: Meta Analysis of Feedback Frequency and Appraisal Reactions

performance appraisal, I was familiar with the criteria by which my performance would be appraised", as well as measures of clarifying expectations, i.e., "raters clarifying performance expectations and the evaluative standards to the employees before the appraisal..." (Shrivastava \& Purang, 2011; see also Thurston, 2001). Several studies also measured goal setting before the appraisal, such as Evans and McShane, which they defined as "the process by which performance-related goals for the employee's current job are established" (pg. 182), and Dipboye and DePontbriand (1981), which measured both goal setting before the review and whether objectives were set during the review period,.

Performance rating favorability was coded across studies. Examples include feedback sign, e.g., the proportion of favorable performance appraisal feedback to negative feedback (Kinicki et al., 2004), and employee performance or the employee's performance rating (Klein \& Snell, 1994).

Two researchers familiar with the performance appraisal literature (the first author of this study and a trained graduate student) independently coded the effect sizes in this study. Level of agreement for both frequent feedback and knowledge of standards was $85 \%$.

Appraisal reactions. As described above, a variety of criteria are used to measure appraisal reactions, including perceptions of performance appraisal accuracy and fairness, satisfaction with the appraisal, motivation to improve performance, perceptions of organizational justice and overall or composite measures of reactions (Keeping \& Levy, 2000). Similar to previous meta-analyses of the appraisal reactions literature (Cawley, Keeping \& Levy, 1998; Pichler, 2012), when meta-analyzing overall relationships between adequate notice and appraisal reactions, multiple reaction criteria were included; the are not yet enough studies to enable meta-analyses of relationships with multiple distinct specific criteria. 
RUNNING HEAD: Meta Analysis of Feedback Frequency and Appraisal Reactions

\section{Meta-Analytic Method}

The effect size metric chosen was the correlation coefficient, as effect sizes reported in the performance appraisal literature are generally reported in this metric. Correlations were first transformed into the Fisher's $\mathrm{z}$ for analysis, and were then back- transformed into the correlation metric. Each effect size was weighted by the inverse of its sampling error variance. Tests of significance for effect size centrality were conducted using Z-tests (Lipsey \& Wilson, 2001). Since effect size distributions were heterogeneous, random effects models were employed for $M r$ and its confidence interval (Hedges \& Vevea, 1998; see Table $1^{1}$ ).

Significance tests for moderation (with continuous moderators) were conducted using procedures developed for meta-analytic regression in SPSS by Lipsey and Wilson (2001), i.e., inverse variance weighted regression analysis. A modified weighted least squares regression approach was used to test hypotheses involving moderation with continuous moderators (Lipsey \& Wilson, 2001, pg. 141).

Procedures for testing and reporting effect size centrality, homogeneity and moderation were consistent with convention (Hedges \& Olkin, 1985), as well as papers published in the human resource management literature (e.g., Pichler, 2012; Schneid, Isidor, Li, \& Kabst, 2015).

\section{Results}

\section{Meta-Analytic Correlations}

Meta-analytic correlations between each of the independent variables in this study and employee reactions are reported in Table 1. A list of primary studies, variables coded and effect sizes included in the database is given in the Appendix. As hypothesized, knowledge of

1 In response to a reviewer request, we also ran our analyses using methods outlined by Hunter \& Schmidt (2014), i.e., population estimates corrected for measurement error. Results are the same, except that these estimates are larger: For Frequent Feedback, $\rho=.50[80 \% \mathrm{CI}=.24, .77]$. For Knowledge of Performance Standards, $\rho=.50$ $[80 \% \mathrm{CI}=.30, .71] . \mathrm{CI}=$ credibility interval. 
RUNNING HEAD: Meta Analysis of Feedback Frequency and Appraisal Reactions

performance standards and feedback frequency were both positively related to employee reactions. Both aspects of adequate notice, i.e., knowledge of performance standards $(M r=.49$, $\mathrm{k}=19)$ and frequent feedback $(M r=.45, k=18)$, were correlated with overall reactions. Thus, hypotheses 1 and 2 were supported. After computing mean effect sizes, we calculated Failsafe N's, using Orwin's (1983) formula, for each effect size to establish if publication bias might be a likely threat to the validity of our results.. These computations revealed that it would take 18 studies to reduce the $M r=.45$ in half, to .225 , and it would take 19 studies to reduce the $M r=$ .49 in half, to .25 . Thus, publication bias does not seem a likely threat to the validity of our results.

-----Insert Table 1 here-----

\section{Tests of Moderation}

Results of moderator analyses are reported in Table 2. Hypothesis 3 predicted that the relationship between feedback frequency and employee reactions would be moderated by knowledge of performance standards. The relationship between feedback frequency and employee reactions was significantly heterogeneous $(Q=290.35 \mathrm{p}<.05$; Table 1$)$, and was moderated by knowledge of performance standards in the expected direction $\left(B=.1 .35, R^{2}=.48\right.$, $k=8$ ). Hypothesis 4 predicted that the relationship between feedback frequency and employee reactions would vary according to rating favorability, i.e. that the relationship would become stronger as the relationship between rating favorability and employee reactions increased. The relationship between feedback frequency and employee reactions was moderated by rating favorability in the expected direction $\left(B=.56, R^{2}=.05, k=11\right)$. Thus, both hypothesis 3 and 4 were supported.

\section{Discussion}


RUNNING HEAD: Meta Analysis of Feedback Frequency and Appraisal Reactions

Performance appraisal is one of the most researched topics in human resource management, and employee reactions to appraisals are an important outcome of the appraisal process. Some scholars and practitioners say it is the most important outcome. Yet, there has been a critical science-practice gap (Balzer \& Sulsky, 1990; Levy \& Williams, 2004) in this literature as research has not produced a coherent explanation for different employee reactions to appraisals. The scholarly literature traditionally has overemphasized the psychometric properties of appraisals, and underemphasized the appraisal process. In response to criticisms from both the scholarly and practitioner communities, researchers have shifted their focus to contextual aspects of the formal appraisal and to employee reactions to appraisals (e.g., Levy \& Williams, 2004; Pichler, 2012). We investigated how an important set of due process constructs relate to appraisal reactions, i.e., knowledge of performance standards and frequent feedback, and the boundary conditions of the relationship between feedback frequency and appraisal reactions. Although relationships between feedback frequency and appraisal reactions are inconsistent in primary studies, meta-analysis shows this relationship to be moderately strong, and moderated by knowledge of performance standards and performance rating favorability.

\section{Implications for theory and research}

Feedback frequency has received significant attention in performance appraisal research for decades, and has been a central construct for understanding the feedback environment of performance appraisal (e.g. Kinicki et al., 2004), performance management process (Ilgen et al., 1979; Klein \& Snell, 1994), and reactions to performance appraisals (Kinicki et al., 2001). These theoretical models would suggest that there should be a consistently positive and practically significant relationship between feedback frequency and reactions to performance appraisals. This has not been borne out by the empirical literature which has shown inconsistent results across 
RUNNING HEAD: Meta Analysis of Feedback Frequency and Appraisal Reactions

studies (cf. Table 1). This meta-analysis reveals that in general across studies, there is an overall significant and moderately strong relationship between feedback frequency and appraisal reactions, which is consistent with theory. That said, it is also important to try to explain the variability in the relationship between feedback frequency and appraisal reactions across studies. Theoretical models of the feedback process highlight the importance of the favorability of feedback (e.g., Ilgen et al., 1979), yet these models have not proposed how frequent feedback and feedback sign might interactively be related to performance appraisal reactions.

We accordingly proposed that feedback frequency has an interactive relationship with performance rating favorability on appraisal reactions. This hypothesis was supported, explaining some of the variability in the relationship between feedback frequency and appraisal reactions. More specifically, we found that the relationship between feedback frequency and appraisal reactions was stronger when feedback was more positive. This could suggest that employees tend to perform better across time with more frequent feedback, and thus react more favorably to their performance appraisals. It could also suggest that employees may develop expectations of more favorable performance ratings with more frequent feedback, and when these expectations are met, they react more favorably to the appraisal. Such propositions can be explored empirically in future research.

While researchers and practitioners have touted the importance of ongoing feedback for employees, our results provide empirical support for this critical practice. Our findings also suggest that knowledge of standards is an important predictor of appraisal reactions. Due process theory is consistently viewed as a useful lens through which to examine fairness in performance appraisals (Abzug \& Mezias, 1993; Levy et al., 2015), which suggests that adequate notice is critical for favorable reactions to the appraisal process. Our model which combines feedback frequency and 
RUNNING HEAD: Meta Analysis of Feedback Frequency and Appraisal Reactions

knowledge of performance standards, suggests both are important, and that there is an interactive relationship between feedback frequency and knowledge of performance standards as related to performance appraisal reactions. Our meta-analytic results support our model. Since performance feedback is not very useful without knowledge of performance standards, the two appear to be complementary. It may be that frequent feedback is a necessary but insufficient condition for reactions to appraisal to be positive, in the sense that knowledge of performance standards is a key variable that amplifies this relationship. We provide a new way of understanding the relationship between feedback frequency and appraisal reactions in terms of moderators of this relationship, as seen in Figure 1. Future research should consider this complementary or synergistic relationship between knowledge of performance standards and feedback frequency.

We also suggest that future research examine the level of employee knowledge of other HRM practices as a predictor of reactions to those practices, thus extending the due process model of performance appraisal to other areas of HR. There is an increasing body of research on employee perceptions of HR practices (e.g., Boon, Den Hartog, Boselie, \& Pauuwe, 2011), including outcomes of these perceptions and mediators of the perceptions-outcomes relationship (e.g., Dearle, Den Hartog, Weibel, Gillespie, Six, Hatzakis, \& Skinner, 2011; Jensen, Patel, \& Memmersmith, 2011). That said, there is less research on antecedents of employee perceptions of HR practices (e.g., Den Hartog, Boon, Verburg, \& Croon, 2012). Due process theory suggests that adequate notice is paramount to reactions to performance appraisal reactions, and this may be the case with other HR practices and systems as well.

\section{Implications for human resource management}

Performance appraisal reactions are a key indicator of performance appraisal effectiveness (e.g., Cawley, Keeping \& Levy, 1998; Levy \& Williams 2004; Pichler, 2012). Some studies have 
RUNNING HEAD: Meta Analysis of Feedback Frequency and Appraisal Reactions

found that appraisal reactions influence subsequent job performance (Anseel et al., 2011; Jawahar, 2010). The relationship between appraisal reactions and performance may be more nuanced than a simple direct effects model (see Kuvaas, 2011), but understanding how feedback is related to appraisal reactions provides insight into the link between feedback and job performance. In other words, we assert that frequent feedback combined with knowledge of performance standards may be helpful not only for improving performance appraisal reactions, but also for subsequent improvements in job performance. In fact, it is more likely that reactions to feedback predict future job performance, not feedback per se (Jawahar, 2010).

This matters because scholars have criticized the performance feedback literature for focusing on direct relationships between feedback and outcomes, such as job performance, without considering mediating or moderating processes (Anseel et al., 2011; Kinicki et al., 2004; Kuvaas, 2006; 2011; Lurie \& Smawinathan, 2009). Such processes are important for understanding both how to manage performance appraisal effectiveness. The finding that performance rating favorability moderates the relationship between feedback frequency and appraisal reactions is consistent with previous research, which has demonstrated an interaction between feedback frequency and constructiveness as related to job performance (Kuvaas et al., 2016). An implication of our results is that managers should be aware of the potential ramifications of regular performance conversations, including that employees may begin to expect more favorable ratings. This is consistent with the arguement that adequate notice can raise employee's expectations in addition to giving them voice (Cropanzano et al., 2001: 45).

Finding that the relationship between feedback frequency and appraisal reactions is moderated by knowledge of performance standards suggests that managers should implement processes to increase employee knowledge of performance standards, using both informal and 
RUNNING HEAD: Meta Analysis of Feedback Frequency and Appraisal Reactions

formal channels. For example, some organizations such as AT\&T expect managers to have recurring informal conversations with subordinates to clarify performance standards and improve employee skills. Publishing performance standards for specific job families in organizational handbooks could be a helpful formal channel, with the caveat that complex heuristic jobs may require more fungible performance standards than simple algorithmic jobs. Overall, performance feedback should take on a developmental tone if it is expected to facilitate performance gains for workers (Combs, Liu, Hall \& Ketchen, 2006). Increasing supervisor-subordinate discussions of performance standards and goals throughout the year (not just during the appraisal session) would be a helpful informal channel (Levy et al., 2015). Employee knowledge of performance standards should benefit both employees and their employers. For the performance management system to have an effect on an organization's bottom line and thus contribute to organizational effectiveness, managers need to make organizational goals and standards salient to employees by linking them to performance assessment.

Overall, our results suggest that organizations will benefit from implementing both aspects of the adequate notice dimensions of due process. The due process theory of performance appraisal also includes a fair hearing (employees can participate in the appraisal and present a defense of their perspective of their performance), and judgment based on evidence (which includes a fair and unbiased evaluator and system features, such as an appeals process). Although we were not able to include all these aspects of due process in our study, the literature suggests that performance appraisal processes will be optimally effective to the extent that all aspects of due process operate in concert. That said, as Levy et al. (2015) pointed out, implementing all aspects of due process in a single organization is complicated, and requires substantial resources (e.g., process design, manager training). Human resource managers should consider which aspects of due process are 
RUNNING HEAD: Meta Analysis of Feedback Frequency and Appraisal Reactions

most relevant to their organizations based judgments about the return on such investments or fit with organizational culture.

\section{Limitations and directions for future research}

As is the case with much of the empirical research in the organizational sciences, and with meta-analyses of this literature (e.g. Cohen-Carash \& Spector, 2001; Colquitt et al., 2001), the effect sizes included in the database for this meta-analysis were based on cross-sectional, perceptpercept data. This is a concern not only because of the potential for inflated effect sizes, but also because it limits the extent to which research sheds light on the dynamic processes by which employee reactions occur. Nonetheless, meta-analysis allows for 1) stable estimates of bivariate relationships, which is important here given prior discrepancies in the relationships between frequent feedback and appraisal reactions, 2) tests of moderators of bivariate relationships, which meant in this case we were able to assess rating favorability and knowledge of performance standards as potential moderators of relationships between feedback frequency and employee reactions.

Since meta-analyses can only include variables that are available from primary studies, we were unable to assess other dimensions of feedback (besides frequency) such as the nature, timing, source and quality. The feedback environment scale (FES) measures multiple dimensions of performance feedback (e.g., feedback quality, promotion of feedback seeking) from both supervisors and coworkers (Steelman, Levy \& Snell, 2004). Future research could focus on feedback frequency and the feedback environment to better understand reactions to performance appraisal. We also could not control for other relevant variables, such as the extent of subordinate participation in goal-setting, supervisor appraisal training, or performance-based pay. Future work could aim to overcome these weaknesses by designing studies that also include other dimension 
RUNNING HEAD: Meta Analysis of Feedback Frequency and Appraisal Reactions

of due process. Perhaps more importantly, future research should test the causal paths we posited which include learning, organizational justice and well-being as mediators of the feedback frequency to appraisal reaction relationship. Several moderators also should be included in future research.

First, some of the omitted variables in primary mentioned above, such as supervisor appraisal training, may be included. Furthermore, the psycho-social relationship of the supervisor and subordinate may be conducive to enhancing the effectiveness of feedback by addressing psychological needs for autonomy, competence and relatedness (Beenen, Pichler \& Levy, 2017). Second, individual differences could be allowed for: including their job demands and extent of control, intrinsic versus extrinsic motivational preferences (Ryan \& Deci, 2000; see Kuvaas, 2007), feedback orientation (Linderbaum and Levy, 2010), mastery orientation (London and Smither, 2002), core self-evaluation (Judge, Erez, Bono \& Thoreson, 2003), and personality factors such as conscientiousness, openness or trait negative affectivity. For example, somebody with very high demands and low control might respond less favorably to feedback, especially negative feedback. In contrast a highly conscientious and open person may be more responsive to both positive and negative feedback.

As appraisal is an ongoing process, studies should examine the dynamics of that process. For instance, appraisal reactions in one period may improve goal-setting in the next. Longitudinal research could examine upward performance spirals such as whether appraisal processes deemed as fair and satisfactory lead to increased performance, which then leads to more positive supervisor-subordinate interactions, which in turn leads to more frequent feedback and discussion of performance standards during the next appraisal period, followed by more favorable reactions, and so on. Conversely, appraisal processes that are deemed to be unfair and unsatisfactory may 
RUNNING HEAD: Meta Analysis of Feedback Frequency and Appraisal Reactions

lead to downward performance spirals and less positive experiences during the next appraisal session and, perhaps ultimately, increased burnout, and lower commitment and retention. Studies which measure perceptions of appraisal processes, reactions to appraisals and job performance at multiple points in time over more than one appraisal period are therefore highly desirable.

\section{Conclusion}

We have integrated theory and research on performance feedback with the due process model of performance appraisal to more fully understand how feedback frequency and knowledge of performance standards each contributes to favorable reactions to the performance appraisal itself. We also showed how prior inconsistencies in the literature regarding the relationship of feedback frequency to appraisal reactions may reflect, at least partly, the moderating effects of knowledge of performance standards and performance rating favorability, although across studies the direct effect was validated. We hope that our model which shows how feedback frequency, knowledge of performance standards and performance rating favorability are related to performance appraisal reactions (Figure 1), can guide future research. By further exploring these relationships, scholars and practitioners should be able to design studies and interventions that improve the effectiveness of performance appraisals, resulting in higher employee performance and all the benefits that go with it. 
RUNNING HEAD: Meta Analysis of Feedback Frequency and Appraisal Reactions

\section{References}

Abzug, R., \& Mezias, S. J. (1993). The fragmented state and due process protections in organizations: The case of comparable worth. Organization Science, 4(3), 433-453.

Aguinis, H. (2013). Performance management (3rd ed.). Upper Saddle River, NJ: Pearson Prentice Hall.

Anseel, F., Van Yperen, N. W., Janssen, O., \& Duyck, W. (2011). Feedback type as a moderator of the relationship between achievement goals and feedback reactions. Journal of Occupational and Organizational Psychology, 84(4), 703-722.

Alvero, A. M., Bucklin, B. R., \& Austin, J. (2001). An objective review of the effectiveness and essential characteristics of performance feedback in organizational settings (1985-1998). Journal of Organizational Behavior Management, 21(1), 3-29.

Ashford, S. J., \& Cummings, L. L. (1983). Feedback as an individual resource: Personal strategies of creating information. Organizational Behavior and Human Performance, 32(3), 370-398.

*Ayers, R.S. (2010). Looking for results: Implementing federal agency strategic plans through performance appraisal programs. Unpublished Doctoral Dissertation: North Carolina State University.

Balzer, W.K., Sulsky, L.M. (1990). Performance appraisal effectiveness. In Murphy, K.R., Saal, F.E. (Eds), Psychology in Organizations: Integrating Science and Practice. Erlbaum, Hillsdale, NJ, pp.133-56.

Becker, J., Bridge, P., Brown, E., Lusk, R., \& Ferrari-Anderson, J. (2015). Evaluation of a performance appraisal framework for radiation therapists in planning and simulation. Journal of Medical Radiation Sciences, 62(2), 114-121. 
RUNNING HEAD: Meta Analysis of Feedback Frequency and Appraisal Reactions

Beenen, G., Pichler, S., \& Levy, P.E. (2017). Self-determined feedback seeking: The role of perceived supervisory autonomy support. Human Resource Management, 56(4), 555-569..

Bies, R.J., \& Moag, J.S. (1986). Interactional justice: Communication criteria of fairness. Research on Negotiation in Organizations. JAI Press.

Biron, M., Farndale, E., \& Paauwe, J. (2011). Performance management effectiveness: lessons from world-leading firms. The International Journal of Human Resource Management, 22(06), 1294-1311.

Blakely, G. L. (1993). The effects of performance rating discrepancies on supervisors and subordinates. Organizational Behavior and Human Decision Processes, 54(1), 57-80.

Boon, C., Den Hartog, D. N., Boselie, P., \& Paauwe, J. (2011). The relationship between perceptions of HR practices and employee outcomes: examining the role of personorganisation and person-job fit. The International Journal of Human Resource Management, 22(01), 138-162.

Brett, J. F., \& Atwater, L. E. (2001). 360 feedback: Accuracy, reactions, and perceptions of usefulness. Journal of Applied Psychology, 86(5), 930.

*Buehler, L.M. (2006). Due process dimensions of performance appraisal, perceptions of organizational justice, and some outcomes. Unpublished Doctoral Dissertation, DePaul University.

Carver, C. S., \& Scheier, M. F. (1981). Attention and self-regulation: A control-theory approach to human behavior. New York: Springer.

Carver, C. S., \& Scheier, M. F. (1990). Origins and functions of positive and negative affect: a control-process view. Psychological review, 97(1), 19.

Cawley, B.D., Keeping, L.M., \& Levy, P.E. (1998). Participation in the performance appraisal 
RUNNING HEAD: Meta Analysis of Feedback Frequency and Appraisal Reactions

process and employee reactions: A meta-analytic review of field investigations. Journal of Applied Psychology, 83 (4), 615-633.

Cederblom, D. (1982). The performance appraisal interview: A review, implications, and suggestions. Academy of Management Review, 7(2), 219-227.

Chhokar, J. S., \& Wallin, J. A. (1984). A field study of the effect of feedback frequency on performance. Journal of Applied Psychology, 69(3), 524.

Cleveland, N. J., \& Murphy, K. R. (1992). Analysis of performance appraisal as goal-directed behavior. In G. Ferris \& K. Rowland (Eds.), Research in personnel and human resource management (Vol. 10, pp. 121-185). Greenwich, CT: JAI Press.

Cohen-Charash, Y., \& Spector, P. E. (2001). The role of justice in organizations: A metaanalysis. Organizational Behavior and Human Decision Processes, 86, 278-321.

Colquitt, J.A., Wesson, M.J., Porter, C.O.L.H., Conlon, D.E., Ng, K.Y. (2001). Justice at the millennium: A meta-analytic review of 25 years of organizational justice research. Journal of Applied Psychology, 86, 425-46.

Conway, J. M., \& Huffcutt, A. I. (1997). Psychometric properties of multisource performance ratings: A meta-analysis of subordinate, supervisor, peer, and self-ratings. Human Performance, 10(4), 331-360.

Combs, J., Liu, Y., Hall, A., \& Ketchen, D. (2006). How much do high-performance work practices matter? A meta-analysis of their effects on organizational performance. Personnel Psychology, 59, 501-528

Cropanzana, R., Bowen, D. E., \& Gilliland, S. W. (2007). The management of organizational justice. The Academy of Management Perspectives, 34-48.

Den Hartog, D. N., Boon, C., Verburg, R. M., \& Croon, M. A. (2013). HRM, communication, 
RUNNING HEAD: Meta Analysis of Feedback Frequency and Appraisal Reactions

satisfaction, and perceived performance: A cross-level test. Journal of management, 39(6), 1637-1665.

*Dipboye, R. L., \& De Pontbriand, R. (1981). Correlates of employee reactions to performance appraisals and appraisal systems. Journal of Applied psychology, 66(2), 248.

*Dobbins, G.H., Cardy, R.L., \& Platz-Vieno (1990). A contingency approach to appraisal satisfaction: An initial investigation of the joint effects of organizational variables and appraisal characteristics. Journal of Management, 3, 619-632.

Erdogan, B. (2002). Antecedents and consequences of justice perceptions in performance appraisals. Human Resource Management Review, 12, 555-578.

*Erdogan, B., Kraimer, M.L., \& Liden, R.C. (2001). Procedural justice as a two-dimensional construct: An examination in the performance appraisal context. Journal of Applied Behavioral Science, 37, 205-222.

*Evans, E.M., \& McShane, S.L. (1988). Employee perceptions of performance appraisal fairness in two organizations Canadian Journal of Behavioral Science, 20 (2), 177-191.

Farndale, E., \& Kelliher, C. (2013). Implementing performance appraisal: Exploring the employee experience. Human Resource Management, 52(6), 879-897.

Fedor, D. B., Eder, R. W., \& Buckley, M. R. (1989). The contributory effects of supervisor intentions on subordinate feedback responses. Organizational Behavior and Human Decision Processes, 44(3), 396-414.

*Feys, M., Libbrecht, N., Anseel, F., \& Lievens, F. (2008). A closer look at the relationship between justice perceptions and feedback reactions: The role of the quality of the relationship with the supervisor. Psychologica Belgica, 48 (2/3), 127-156.

Folger, R., Konovsky, M., \& Cropanzano, R. (1992). A due process model of performance 
RUNNING HEAD: Meta Analysis of Feedback Frequency and Appraisal Reactions

appraisal. In B. M. Staw \& L. L. Cummings (Eds.), Research in organizational behavior (Vol. 14, pp. 129-177). Greenwich, CT: JAI Press.

*Gaby, S.H. (2004). Summarizing and measuring participants' perceptions related to performance appraisal effectiveness. Unpublished Doctoral Dissertation, University of Tennessee, Knoxville.

Greenberg, J. (1987). A taxonomy of organizational justice theories. Academy of Management Review, 12, 9-22.

Greenberg, J. (1990). Organizational justice: Yesterday, today, and tomorrow. Journal of Management, 16, 399-432.

Greller, M. M. (1975). Subordinate participation and reactions to the appraisal interview. Journal of Applied Psychology, 60(5), 544.

Greller, M. M., \& Parsons, C. K. (1992). Feedback and feedback inconsistency as sources of strain and self-evaluation. Human Relations, 45(6), 601-620.

Hedges, L.V. \& Olkin, I. (1985). Statistical methods for meta-analysis. Orlando: Academic Press.

Hedges, L.V., \& Vevea, J.L. (1998). Fixed and random-effects models in meta-analysis. Psychological Methods, 3, 486-504.

Holzbach, R. L. (1978). Rater bias in performance ratings: Superior, self-, and peer ratings. Journal of Applied Psychology, 63(5), 579.

Schmidt, F. L., \& Hunter, J. E. (2014). Methods of meta-analysis: Correcting error and bias in research findings. Sage publications.

Ilgen, D.R., Fisher, C.D., \& Taylor, M.S. (1979). Consequences of individual feedback on 
RUNNING HEAD: Meta Analysis of Feedback Frequency and Appraisal Reactions

behavior in organizations. Journal of Applied Psychology, 64, 349-371.

Ilgen, D. R., \& Hamstra, B. W. (1972). Performance satisfaction as a function of the difference

between expected and reported performance at five levels of reported performance. Organizational Behavior and Human Performance, 7(3), 359-370.

*Inderriden, E.J., Allen, R.E., Keavey, T.J. (2004). Managerial discretion in the use of selfratings in an appraisal system: The antecedents and consequences. Journal of Managerial Issues, $16(4), 460-482$.

Ivancevich, J. M. (1982). Subordinates' reactions to performance appraisal interviews: A test of feedback and goal-setting techniques. Journal of Applied Psychology, 67(5), 581.

Jawahar, I. M. (2010). The mediating role of appraisal feedback reactions on the relationship between rater feedback-related behaviors and ratee performance. Group \& Organization Management, 35(4), 494-526.

Jensen, J. M., Patel, P. C., \& Messersmith, J. G. (2013). High-performance work systems and job control: Consequences for anxiety, role overload, and turnover intentions. Journal of Management, 39(6), 1699-1724.

Judge, T. A., Erez, A., Bono, J. E., \& Thoresen, C. J. (2003). The core self-evaluations scale: Development of a measure. Personnel psychology, 56(2), 303-331.

Keeping, L.M., \& Levy, P.E. (2000). Performance appraisal reactions: Measurement, modeling, and method bias. Journal of Applied Psychology, 85 (5), 708-723.

*Kavanagh, P., Benson, J., \& Brown, M. (2007). Understanding performance appraisal fairness Asia Pacific Journal of Human Resources, 45 (2), 132 - 150.

*Kinicki, A.J., Prussia, G.E., Wu, B., \& Mckee-Ryan, F.M. (2004). A covariance structure 
RUNNING HEAD: Meta Analysis of Feedback Frequency and Appraisal Reactions

analysis of employee's response to performance feedback. Journal of Applied Psychology, 89 (6), 1057-1069.

*Klein, H.J., \& Snell, S. (1994). The impact of interview process and context on performance appraisal interview effectiveness. Journal of Managerial Issues, 6 (2), 160-175.

Kluger, A.N. \& DeNisi, A. (1996). The effects of feedback interventions on performance: A

historical review, a meta-analysis, and a preliminary feedback intervention theory. Psychological Bulletin, 119, 254-284.

*Kuvaas, B. (2011). The interactive role of performance appraisal reactions and regular feedback. Journal of Managerial Psychology, 26 (2), 123-137.

Kuvaas, B. (2006). Performance appraisal satisfaction and employee outcomes: mediating and moderating roles of work motivation. The International Journal of Human Resource Management, 17(3), 504-522.

Kuvaas, B. (2007). Different relationships between perceptions of developmental performance appraisal and work performance. Personnel Review, 36(3), 378-397.

Kuvaas, B., Buch, R., \& Dysvik, A. (2016). Constructive Supervisor Feedback is not Sufficient: Immediacy and Frequency is Essential. Human Resource Management.

Lam, C. F., DeRue, D. S., Karam, E. P., \& Hollenbeck, J. R. (2011). The impact of feedback frequency on learning and task performance: Challenging the "more is better" assumption. Organizational Behavior and Human Decision Processes, 116 (2), 217-228.

*Landy, F.J., Barnes, J.L., \& Murphy (1978). Correlates of perceived fairness and accuracy of evaluation. Journal of Applied Psychology, 63 (6), 751-754.

Latham, G. P., Fay, C. H., \& Saari, L. M. (1979). The development of behavioral observation scales for appraising the performance of foremen. Personnel Psychology, 32(2), 299-311. 
RUNNING HEAD: Meta Analysis of Feedback Frequency and Appraisal Reactions

Leventhal, G.S. (1980). What should be done with equity theory?. In: K.J. Gergen, M.S. Greenberg, \& R.H. Willis, (Eds), Social exchange: Advances in theory and research. Plenum: New York. (pp. 27-55).

Levy, P.E., Cavanaugh, C.M, Frantz, N.B., \& Borden, L.A. (2015). The role of due process in performance appraisal: A 20-year retrospective. In R. S. Cropanzano \& M.L.Ambrose (Eds.). The Oxford Handbook of Justice in the Workplace, NY: Oxford University Press, 605-620.

Levy, P.E., Cawley, B.D., \& Foti, R. (1998). Reactions to appraisal discrepancies: Performance ratings and attributions. Journal of Business and Psychology, 12 (4), 437-455.

*Levy, P.E. \& Williams, J.R. (1998). The role of perceived system knowledge in predicting appraisal reactions, job satisfaction, and organizational commitment. Journal of Organizational Behavior, 19, 53-65.

Levy, P.E. \& Williams, J.R. (2004). The social context of performance appraisal. Journal of Management, 30 (6), 881-905.

Lind, E.A., \& Tyler, T.R. (1988). The social psychology of procedural justice. N.Y.: Plenum. Linderbaum, B. A., \& Levy, P. E. (2010). The development and validation of the Feedback Orientation Scale (FOS). Journal of Management, 36(6), 1372-1405.

Lipsey, M.W., \& Wilson, D.B. (2001). Practical meta analysis. Applied Social Research Methods Series, vol. 49. Thousand Oaks: Sage.

London, M., \& Smither, J. W. (2002). Feedback orientation, feedback culture, and the longitudinal performance management process. Human Resource Management Review, 12(1), 81-100.

Lurie, N. H., \& Swaminathan, J. M. (2009). Is timely information always better? The effect of 
RUNNING HEAD: Meta Analysis of Feedback Frequency and Appraisal Reactions

feedback frequency on decision making. Organizational Behavior and Human Decision Processes, 108(2), 315-329.

Mackie, K. S., Holahan, C. K., \& Gottlieb, N. H. (2001). Employee involvement management practices, work stress, and depression in employees of a human services residential care facility. Human Relations, 54(8), 1065-1092.

Mesch, D. J., Farh, J. L., \& Podsakoff, P. M. (1994). Effects of feedback sign on group goal setting, strategies, and performance. Group \& Organization Management, 19(3), 309-333.

Nunnally, J. C., \& Bernstein, I. H. (1994). Psychological theory. New York, NY: McGraw-Hill.

Podsakoff, P. M., \& Farh, J. L. (1989). Effects of feedback sign and credibility on goal setting and task performance. Organizational Behavior and Human Decision Processes, 44(1), $45-67$.

Pichler, S. (2012). The social context of performance appraisal and appraisal reactions: A metaanalysis. Human Resource Management, 51 (5), 709-732.

Pichler, S., Varma, A., Michel, J.S. Levy, P.E. \& Budwar, P.S. (2016). Leader-Member Exchange, Group and Individual-Level Procedural Justice Reactions to Performance Appraisals. Human Resource Management, 55 (5), 871-883.

Rosenthal, R., \& DiMatteo, M. R. (2001). Meta-analysis: Recent developments in quantitative methods for literature reviews. Annual review of psychology, 52(1), 59-82.

Ryan, R. M., \& Deci, E. L. (2000). Self-determination theory and the facilitation of intrinsic motivation, social development, and well-being. American psychologist, 55(1), 68.

*Scott, D. (2015). Performance feedback and impact on work motivation. Unpublished Masters Thesis, Universitet i Stavanger.

Searle, R., Den Hartog, D. N., Weibel, A., Gillespie, N., Six, F., Hatzakis, T., \& Skinner, D. 
RUNNING HEAD: Meta Analysis of Feedback Frequency and Appraisal Reactions

(2011). Trust in the employer: The role of high-involvement work practices and procedural justice in European organizations. The International Journal of Human Resource Management, 22(05), 1069-1092.

*Secunda, M.D. (1984). Employee perceptions of performance appraisal systems: Causal determinants of fairness, accuracy, and acceptability. Unpublished doctoral dissertation, Old Dominion University.

*Shrivasatva, A., \& Purang, P. (2011). Employee perceptions of performance appraisals: A comparative study on Indian banks. International Journal of Human Resource Management, 22 (3), 632-647.

Steelman, L. A., Levy, P. E. and Snell, A. F. (2004) The feedback environment scale: Construct Definition, Measurement, and Validation. Educational and Psychological Measurement, $64,164-184$

*Steensma, H., \& Otto, L. (2000). Perception of performance appraisal by employees and supervisors: Self-serving bias and procedural justice. Journal of Collective Negotiations, $29(4), 307-319$.

Taylor, M.S., Tracy, K.B., Renard, M.K., Harrison, J.K., \& Carroll, S.J. (1995). Due process in performance appraisal: A quasi-experiment in procedural justice. Administrative Science Quarterly, 40, 495-523.

*Tang, T.L.P., \& Sarsfield-Baldwin, L.J. (1996). Distributive and procedural justice as related to satisfaction and commitment. Paper Presented at the Annual Meeting of the Southwestern Psychological Association, Houston, TX.

*Thurston, P.W. (2001). Clarifying the structure of justice using fairness perceptions of performance appraisal practices. Unpublished Doctoral Dissertation, University at 
RUNNING HEAD: Meta Analysis of Feedback Frequency and Appraisal Reactions

Albany, State University of New York.

*Tuytens, M., \& Devos, G. (2012). Importance of system and leadership in performance appraisal. Personnel Review, 41 (6), 756-776.

Tyler, T.R. (1989). The psychology of procedural justice: a test of the group values model. Journal of Personality and Social Psychology, 57 (5), 830-838.

Tziner, A., Murphy, K.R., Cleveland, J.N. (2005). Contextual and rater factors affecting rating behavior. Group and Organization Behavior, 30 (1), 89-98.

Wang, M., Burlacu, G, Truxillo, D., James, K., \& Yao, X. (2015). Age differences in feedback reactions: The roles of employee feedback orientation on social awareness and utility. Journal of Applied Psychology, 100(4), 1296-1308.

Williams, J. R., \& Levy, P. E. (1992). The effects of perceived system knowledge on the agreement between self-ratings and supervisor ratings. Personnel Psychology, 45, 835847.

*Williams, J.R., \& Levy, P.E. (2000). Investigating some neglected criteria: The influence of organizational level and perceived system knowledge on appraisal reactions. Journal of Business and Psychology, 14 (3), 501-513.

*Wright, R.P. (2004). Mapping cognitions to better understand attitudinal and behavioral responses in appraisal research. Journal of Organizational Behavior, 25, 339-374.

Wood, S. Niven, K. Braeken, J. (in press) Managerial Abuse and the Process Of Absence amongst Mental Health Staff, Work, Employment and Society, in press. On line from January 13, 2016, doi: $10.1177 / 0950017015613755$

Zander, A., \& Gyr, J., (1955). Changing attitudes toward a merit rating system. Personnel Psychology, 8, (1955) 
RUNNING HEAD: Meta Analysis of Frequent Feedback and Appraisal Reactions

\begin{tabular}{|c|c|c|c|c|c|c|c|}
\hline \multicolumn{8}{|c|}{$\begin{array}{l}\text { Table } 1 \\
\text { Meta-analytic Results for Employee Reactions to Performance Appraisal }\end{array}$} \\
\hline & $N$ & $K$ & $S D r$ & $M r$ & $\begin{array}{l}\text { Lower } \\
95 \% \mathrm{CI}\end{array}$ & $\begin{array}{l}\text { Upper } \\
95 \% \mathrm{CI}\end{array}$ & $\mathrm{Q}$ \\
\hline \multicolumn{8}{|c|}{ Adequate Notice } \\
\hline $\begin{array}{l}\text { Frequent } \\
\text { Feedback }\end{array}$ & 5,227 & 18 & .24 & .45 & .33 & .56 & $290.35^{*}$ \\
\hline $\begin{array}{l}\text { Knowledge } \\
\text { of } \\
\text { Performance } \\
\text { Standards }\end{array}$ & 5,445 & 19 & .19 & .49 & .40 & .60 & $201.07 *$ \\
\hline \multicolumn{8}{|c|}{$\begin{array}{l}\text { Note. } N=\text { Cumulative sample size; } k=\text { Cumulative number of effect sizes; } S D r=\text { weighted } \\
\text { standard deviation of observed effect sizes; } M r=\text { Population mean correlation; } Q=\text { heterogeneity of } M r, *= \\
\text { significant at } \mathrm{p}<.05 \text {. Since effect size distributions were heterogeneous, random effects models were employed } \\
\text { for } M r \text { and its confidence interval (Hedges \& Vevea, 1998). For a list of variables coded and effect sizes from } \\
\text { primary studies, see the Appendix. }\end{array}$} \\
\hline
\end{tabular}


RUNNING HEAD: Meta Analysis of Frequent Feedback and Appraisal Reactions

\begin{tabular}{|c|c|c|c|c|c|c|c|c|c|}
\hline \multicolumn{10}{|c|}{$\begin{array}{l}\text { Table } 2 \\
\text { Results of continuous moderator analyses in regression }\end{array}$} \\
\hline $\begin{array}{l}\text { Independent } \\
\text { Variable }\end{array}$ & $\begin{array}{l}\text { Moderator } \\
\text { Variable }\end{array}$ & $\mathrm{k}$ & B & $S E$ & $M r$ & $\begin{array}{l}\text { Lower } \\
95 \% \mathrm{CI}\end{array}$ & $\begin{array}{l}\text { Upper } \\
95 \% \mathrm{CI}\end{array}$ & $\mathrm{Q}$ & $R^{2}$ \\
\hline $\begin{array}{l}\text { Frequent } \\
\text { Feedback }\end{array}$ & $\begin{array}{c}\text { Knowledge of } \\
\text { Performance } \\
\text { Standards }\end{array}$ & 8 & 1.35 & .25 & .54 & .91 & 1.79 & $35.74 *$ & .48 \\
\hline $\begin{array}{l}\text { Frequent } \\
\text { Feedback }\end{array}$ & $\begin{array}{l}\text { Performance } \\
\text { Rating } \\
\text { Favorability }\end{array}$ & 11 & .56 & .18 & .44 & .21 & .91 & $9.58 *$ & .05 \\
\hline
\end{tabular}

Note: $\mathrm{k}=$ number of effect sizes; $\mathrm{B}=$ regression coefficient; $\mathrm{SE}=$ standard error; $\mathrm{Mr}=$ population mean correlation; $\mathrm{Q}=$ heterogeneity of $M r$. 
RUNNING HEAD: Meta Analysis of Frequent Feedback and Appraisal Reactions

Figure 1

Hypothesized Model of the Relationship of Feedback Frequency, Knowledge of Standards, and Rating Favorability on Appraisal Reactions

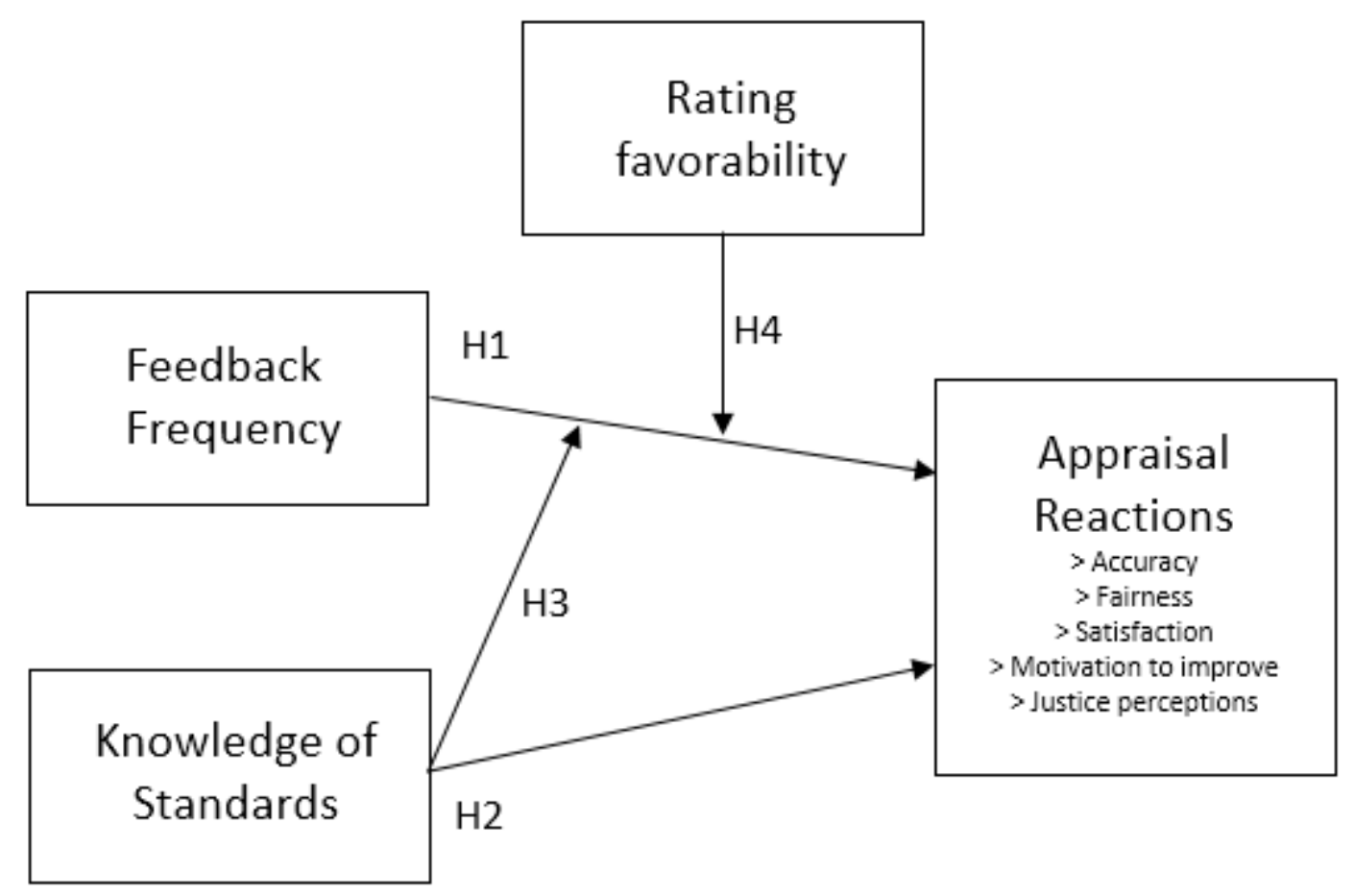


RUNNING HEAD: Meta Analysis of Frequent Feedback and Appraisal Reactions

\begin{tabular}{|c|c|c|c|c|c|c|c|}
\hline \multicolumn{8}{|c|}{$\begin{array}{l}\text { Appendix } \\
\text { List of studies, sample size, variables coded, and effect sizes from primary studies. }\end{array}$} \\
\hline Study & $N$ & FF Measure & $\begin{array}{l}\text { r, } \\
F F, \\
P A R\end{array}$ & KPS Measure & $\begin{array}{l}r, K P S, \\
P A R\end{array}$ & PRF Measure & $\begin{array}{l}r, \\
P R F, \\
P A R\end{array}$ \\
\hline Ayers, 2010 & 146 & & & $\begin{array}{l}\text { Employee } \\
\text { Involvement. }\end{array}$ & .14 & & \\
\hline Buehler, 2006 & 131 & Frequent feedback. & $.46^{*}$ & $\begin{array}{l}\text { Discussed } \\
\text { expectations. }\end{array}$ & $.45 *$ & $\begin{array}{l}\text { Favorability } \\
\text { of } \\
\text { performance } \\
\text { rating. }\end{array}$ & $.52 *$ \\
\hline $\begin{array}{l}\text { Dipboye \& DePontbriand, } \\
1981\end{array}$ & 474 & & & $\begin{array}{l}\text { Perceived goal } \\
\text { orientation. }\end{array}$ & $.57 *$ & & \\
\hline Dobbins et al., 1990 & 165 & $\begin{array}{l}\text { Frequency of } \\
\text { evaluations. }\end{array}$ & .09 & & & $\begin{array}{l}\text { Overall } \\
\text { summary } \\
\text { evaluation. }\end{array}$ & .62 \\
\hline Erdogan et al., 2001 & 84 & $\begin{array}{l}\text { Performance } \\
\text { feedback. }\end{array}$ & .28 & $\begin{array}{l}\text { Knowledge of } \\
\text { appraisal criteria. }\end{array}$ & .23 & & \\
\hline $\begin{array}{l}\text { Evans \& McShane, 1998, } \\
\text { Sample A }\end{array}$ & 214 & $\begin{array}{l}\text { Appraisal frequency } \\
\text { and follow-up. }\end{array}$ & .32 & Goal establishment. & .43 & $\begin{array}{l}\text { Favorableness } \\
\text { of appraisal. }\end{array}$ & .36 \\
\hline $\begin{array}{l}\text { Evans \& McShane, 1998, } \\
\text { Sample B }\end{array}$ & 188 & $\begin{array}{l}\text { Appraisal frequency } \\
\text { and follow-up. }\end{array}$ & .32 & Goal establishment. & .34 & $\begin{array}{l}\text { Favorableness } \\
\text { of appraisal. }\end{array}$ & .29 \\
\hline $\begin{array}{l}\text { Feys et al., 2009, } \\
\text { Study } \# 1\end{array}$ & 218 & $\begin{array}{l}\text { Positive feedback. } \\
\text { (Steelman et al., } \\
\text { 2004). }\end{array}$ & $.61 *$ & & & & $.25^{*}$ \\
\hline $\begin{array}{l}\text { Feys et al., 2009, } \\
\text { Study \#2 }\end{array}$ & 83 & & & $\begin{array}{l}\text { Perceived System } \\
\text { Knowledge. } \\
\text { (Williams \& Levy, } \\
\text { 2000) }\end{array}$ & $.31 *$ & & \\
\hline Gaby, 2004 & 704 & Appraisal frequency. & $.56^{*}$ & & & & \\
\hline
\end{tabular}


RUNNING HEAD: Meta Analysis of Frequent Feedback and Appraisal Reactions

\begin{tabular}{|c|c|c|c|c|c|c|c|}
\hline Study & $N$ & FF Measure & $\begin{array}{l}\boldsymbol{F}, \\
P A R \\
\end{array}$ & KPS Measure & $\begin{array}{l}r, K P S, \\
P A R\end{array}$ & PRF Measure & $\begin{array}{l}\text { r, } \\
P R F, \\
P A R\end{array}$ \\
\hline Inderrieden et al., 2004 & 326 & $\begin{array}{l}\text { Feedback throughout } \\
\text { the evaluation. } \\
\text { (Based on Ilgen et } \\
\text { al., 1981, among } \\
\text { others). }\end{array}$ & .63 & $\begin{array}{l}\text { Knowledge of } \\
\text { performance } \\
\text { standards. }\end{array}$ & .42 & $\begin{array}{l}\text { Work } \\
\text { performance. }\end{array}$ & .52 \\
\hline Kavanagh et al., 2007 & 2377 & & & $\begin{array}{l}\text { Clarity of } \\
\text { performance, } \\
\text { planning \& } \\
\text { evaluation (Tang \& } \\
\text { Sarsfield Baldwin, } \\
\text { 1996) }\end{array}$ & .38 & & \\
\hline Kinicki et al., 2004 & 182 & $\begin{array}{l}\text { Frequency of } \\
\text { feedback. }\end{array}$ & $.44 *$ & & & $\begin{array}{l}\text { Sign of } \\
\text { feedback. }\end{array}$ & $.26^{*}$ \\
\hline Klein \& Snell, 1994 & 55 & PAI Frequency. & .13 & & & $\begin{array}{l}\text { Employee } \\
\text { performance. }\end{array}$ & .25 \\
\hline Landy et al., 1978 & 950 & $\begin{array}{l}\text { Frequency of } \\
\text { performance } \\
\text { evaluation. }\end{array}$ & .33 & & & & \\
\hline $\begin{array}{l}\text { Levy \& Williams, 1998, } \\
\text { Study \#1 }\end{array}$ & 62 & & & $\begin{array}{l}\text { Perceived system } \\
\text { knowledge } \\
\text { (Williams \& Levy, } \\
\text { 1992) }\end{array}$ & .79 & & \\
\hline $\begin{array}{l}\text { Levy \& Williams, 1998, } \\
\text { Study \#2 }\end{array}$ & 48 & & & $\begin{array}{l}\text { Perceived system } \\
\text { knowledge } \\
\text { (Williams \& Levy, } \\
\text { 1992) }\end{array}$ & $.55^{*}$ & & \\
\hline Kuvaas, 2011 & 803 & $\begin{array}{l}\text { Perceived regular } \\
\text { feedback. }\end{array}$ & .48 & & & & \\
\hline Scott, 2001 & 221 & Informal feedback. & .77 & & & & \\
\hline
\end{tabular}


RUNNING HEAD: Meta Analysis of Frequent Feedback and Appraisal Reactions

\begin{tabular}{|c|c|c|c|c|c|c|c|}
\hline Study & $N$ & FF Measure & $\begin{array}{l}r, \\
F F, \\
P A R\end{array}$ & KPS Measure & $\begin{array}{l}r, K P S, \\
P A R\end{array}$ & PRF Measure & $\begin{array}{l}\text { r, } \\
P R F, \\
P A R\end{array}$ \\
\hline $\begin{array}{l}\text { Secunda, 1984, } \\
\text { Study \#1 }\end{array}$ & 208 & $\begin{array}{l}\text { Frequency of } \\
\text { evaluation }\end{array}$ & $.07 *$ & & & $\begin{array}{l}\text { Performance } \\
\text { rating. }\end{array}$ & $.37 *$ \\
\hline $\begin{array}{l}\text { Secunda, 1984, } \\
\text { Study \#2 }\end{array}$ & 208 & $\begin{array}{l}\text { Frequency of } \\
\text { evaluation }\end{array}$ & $.13 *$ & & & $\begin{array}{l}\text { Performance } \\
\text { rating. }\end{array}$ & $.39 *$ \\
\hline Steensma \& Otto, 2000 & 78 & Appraisal frequency. & .31 & Adequate notice. & $\begin{array}{l}.30 \\
(\mathrm{~N}=69)\end{array}$ & & \\
\hline $\begin{array}{l}\text { Shrivasatva, \& Purang, } \\
2011\end{array}$ & 304 & Providing feedback. & $.49 *$ & $\begin{array}{l}\text { Setting \& } \\
\text { Clarifying } \\
\text { expectations. }\end{array}$ & $.45 *$ & & \\
\hline Tang \& Baldwin, 1996 & 110 & & & $\begin{array}{l}\text { Clarity of } \\
\text { performance } \\
\text { standards. } \\
\end{array}$ & $.17^{*}$ & & \\
\hline Thurston, 2001 & 188 & Providing feedback. & $.77 *$ & $\begin{array}{l}\text { Clarifying } \\
\text { expectations. }\end{array}$ & $.79^{*}$ & $\begin{array}{l}\text { Appraisal } \\
\text { perceptions. }\end{array}$ & $.55^{*}$ \\
\hline Tuytens \& DeVos, 2012 & 298 & & & $\begin{array}{l}\text { Standards for } \\
\text { acceptable } \\
\text { performance. }\end{array}$ & $.14^{*}$ & & \\
\hline $\begin{array}{l}\text { Williams \& Levy, 2000, } \\
\text { Sample \# } 1\end{array}$ & 34 & & & $\begin{array}{l}\text { Perceived system } \\
\text { knowledge } \\
\text { (Williams \& Levy, } \\
\text { 1992) }\end{array}$ & .59 & & \\
\hline $\begin{array}{l}\text { Williams \& Levy, 2000, } \\
\text { Sample \# } 2\end{array}$ & 94 & & & $\begin{array}{l}\text { Perceived system } \\
\text { knowledge } \\
\text { (Williams \& Levy, } \\
\text { 1992) }\end{array}$ & .58 & & \\
\hline Wright, 2004 & 51 & & & Clear standards. & .72 & & \\
\hline Total K, Mr & & & $K=18$ & & $K=19$ & & \\
\hline $\begin{array}{l}\text { Total K, } \\
\text { Moderator Analyses }\end{array}$ & & & & $\mathbf{K}=\mathbf{8}$ & & $K=11$ & \\
\hline
\end{tabular}


Notes. $\mathrm{N}$ = study sample size; FF = feedback frequency; KPS = knowledge of performance standards; PRF = performance rating favorability; PAR = performance appraisal reactions. Names of variables from primary studies are included with the citation or source in parentheses, when possible; otherwise, variables were created by the authors in each primary study. $r=$ bivariate correlation from primary study. $*$ = effect size is based on composite correlation. Sample sizes for effect sizes are in parentheses when different from the sample size for feedback frequency, performance appraisal reactions effect size. 